\title{
Birinci Basamak Sağlık Hizmetlerinin Karșılaștırmalı Analizi (Benchmarking): Türkiye ve İspanya Örneği
}

\author{
Comparative Analysis of Primary Health Care (Benchmarking): \\ The Example of Turkey and Spain
}

\author{
Fırat KARA (D, ilkay ÖZTÜRK \\ Bahçeșehir Üniversitesi, Sağlık Hizmetleri Meslek Yüksekokulu, İstanbul, Türkiye
}

ORCID ID: Fırat Kara 0000-0002-5195-4387, ilkay Öztürk 0000-0002-9867-9108

Bu makaleye yapılacak atıf: Kara F ve Öztürk İ. Birinci Basamak Sağlık Hizmetlerinin Karșılaștırmalı Analizi (Benchmarking): Türkiye ve İspanya Örneği. Med J West Black Sea. 2021;5(1):7-18.

Sorumlu Yazar

Firat Kara

E-posta

firat.kara@vsh.bau.edu.tr
Geliș Tarihi

18.07.2020

Revizyon Tarihi

08.12.2020

Kabul Tarihi

10.12.2020 öz

Amaç: Bu araştırmanın amacı karşılaştırmalı sağlık sistemi yönteminden yararlanarak Türkiye ve İspanya'nın birinci basamak sağlık hizmetlerinin kıyaslanmasıdır.

Gereç ve Yöntemler: Araştırma yöntemi olarak betimsel kıyaslamalara dayalı karşılaştırmalı analiz yapılmıştır. Gösterge olarak seçilen Dünya Sağlık Örgütü'nün (WHO) belirlediği gösterge kriterlerine göre yıllar bazında kıyaslama yapılmıştır.

Bulgular: Araştırma sonuçları İspanya'nın ulusal sağlık sistemine sahip olduğu ve birinci basamak sağlık hizmetlerinin finansmanının vergilerle sağlandığı, birinci basamak sağlık harcamalarının toplam sağlık harcamaları içinde yüksek bir paya sahip olduğu, uzman hekimlere ulaşabilmek için aile hekimi tarafından sevk zincirinin etkin olduğu, Türkiye'nin ise sağlık hizmetlerinin finansmanının primlerle sağlandığı, uzman hekimlere ulaşabilmek için aile hekimi tarafından sevk zincirinin zorunlu olmadığı görülmüştür. WHO'nun sağlık göstergelerine göre ise İspanya'nın temel sağlık hizmet çıktılarının çoğunlukla ülkemizden daha olumlu olduğu görülmüştür.

Sonuç: İnsan sağlığını etkileyen binlerce faktör olduğunu göz önüne aldığımızda, toplumların sağlık düzeyini yükseltebilmek için sadece sağlık hizmetlerine odaklanılıp sağlıklı yaşam koşullarını yaratan sağlığın sosyal determinantlarına yeterince eğilmemek istenilen gayeye ulaşılamamasına neden olmaktadır. Temel sağlık hizmetlerinin çıktılarının geliştirilebilmesi için sektörler arası işbirliği, sağlık çalışanlarının performans kriterlerinin İspanya gibi gelişmiş sağlık sistemi bulunan ülkelerden esinlenerek güncellenmesi gerekmektedir. Aynı zamanda sağlık sisteminin etkili, verimli ve etkin hizmet sunabilmesi için sevk zincirinin sağlanmasının yanı sıra ülke içerisinde hizmetlerin hakkaniyetli dağılmasına özen gösterilmelidir.

Anahtar Sözcükler: Aile hekimliği, Birinci basamak sağlık hizmetleri, Kıyaslama, Karşılaştırmalı analiz

\section{ABSTRACT}

Aim: The aim of this study is to compare between Turkey and Spain's primary healthcare (PHC) systems by using comparative healthcare system (HCS) method.

Material and Methods: As a research method, comparative analysis based on descriptive comparisons was made according to the indicator criteria determined by World Health Organization (WHO), which was selected as an indicator.

Results: The results of our study showed that Spain has a national health system (HS) that provided $\mathrm{PHC}$ system by financing tax which have a high share of total health expenditure on PHC spending, the specialist referral by the family physician to reach physicians to be effective, Turkey's HCS provided by 
financing of premiums and the referral chain is not compulsory by the family physician to reach the specialists. According to the WHO criteria, it is seen that the primary health outcomes of Spain are mostly more positive than our country.

Conclusions: Considering that there are thousands of factors affecting human health, it is not possible to reach the desired goal by not focusing on the social determinants of health, which focuses only on health services and creates healthy living conditions in order to increase the health level of the societies. In order to improve the outcomes of PHC services, cross-sectoral cooperation and performance criteria of health care workers should be updated inspired by countries with advanced health systems such as Spain. Also, care should be taken to ensure that the HCS is able to provide effective, efficient and effective services, as well as the equitable distribution of services with in the country.

Keywords: Family practice, Primary healthcare system, Comparison, Comparative analysis

\section{GiRiş}

Benchmarking kavramı, benchmark kelimesinden gelmektedir ve Türkçe karşılığı kıyaslama olarak kullanılır. Bunun dışında referans noktası, kilometre taşı, aşama/evre, bir karşılaştırma ve örnek alma anlamına gelmektedir (1). Küresel rekabetin arttığı son yıllarda kurumlar, kendi uygulamalarını "en iyi" uygulamalarla karşılaştırarak rekabet üstünlüğü elde etmeye çalışırlar. Kıyaslama tekniği, yalnızca "Rakiplerle Karşılaştırma Yapma" anlamına gelmemekte; örgüt içi, sektörel ve genel anlamda çok yönlü araştırma ve karşılaştırmalara olanak tanımaktadır (2). Karşılaştırmalı sağlık sistemleri yaklaşımı ile sağlık hakkının toplum tarafından etkin olarak kullanılabilmesi için ülkeler arasındaki sistemler kıyaslanabilir.

Karşılaştırmalı Sağlık Sistemleri Yaklaşımı; belirlenen hedefleri başarabilmek için gerekli olan bilgilerin, en az iki ülke sağlık sistemlerinin, istenilen alanlarının karşılaştırılması suretiyle elde etmesinin hedeflendiği bir bilimsel araştırma yöntemidir (3).Toplumların gün geçtikçe sağlık konusunda bilinçlenerek daha nitelikli hizmet talep etmeye başlamaları, bilgi teknolojilerinin gelişmesiyle diğer ülke sağlık sistemlerinden haberdar olmaları, sağlığın temel bir insan hakkı olarak kamuoyunda kabul görerek hukuki metinlerde yer almasının artması, hızla kullanımı artan teknolojinin hizmet maliyetlerini de artırması gibi gelişmeler karşılaştırmalı sağlık sistemleri yaklaşımının öneminin artmasında itici gücü sağlamıştır $(3,4)$. Sistem karşılaştırılmasının ana amacı; çalışmayı gerçekleştirenler çeşitli ülke deneyimlerinden istifade ederek yeniliklerin ve metotların öğrenilmek suretiyle mevcuttaki sisteme uyarlanarak entegre edilmesi düşüncesidir (5). Bununla birlikte mevcut problemleri çözmede farklı bakış açıları yakalamak, olası sorunlara karşı proaktif eylem tarzına sahip olabilmek ve hâli hazırdaki sistemin daha etkin, verimli ve etkili çalıştırılabilmesi amacını taşımaktadır (6).

Sağlık sistemlerinin karşılaştırılması ve sınıflandırılması ile ilgili yapılan araştırmalarda sağlık sistemleri belli kategorilere ayrılmıştır; Terris, ülkeleri; Kamuya Dayalı, Sigortaya Dayalı ve Ulusal Sağlık Sistemine sahip olan ülkeler olarak 3 kategoriye ayırmıştır (7). Field ve Mark, ülkeleri az gelişmiş, serbest piyasa tipi, sigorta ve sosyal güvenlik reji- minin etkili olduğu, ulusal sağlık sistemine sahip olanlar ile sosyalist sisteme sahip olanlar olarak beş tipe ayırmıştır (8). Elling ülke sağlık sistemlerini tümüyle kapitalist sistem, sosyal yönelimli kapitalist sistem, endüstrileşmiş sosyalist sistem, kapitalizme bağımlı sistem ve diğerleri şeklinde beş kategoriyle sınıflandırmıştır (9). Roemer ülkeleri girişimci ve serbest, refah yönelimli, bütüncül ve sosyalist (merkezden planlanan) sağlık sistemleri olarak dört grup ayrımına gitmiş ve grupta yer alan ülkeleri de ekonomik gelişmişlik seviyelerine göre ayrıntılı incelemiştir $(10,11)$. Kullanım kolaylığı ve basit uygulama olanağı sağladığı için ülkelerin finansman yöntemlerine göre sınıflandırılması en sık kullanılan yöntemlerin başında gelmektedir. Bu yönteme göre ülkeler hizmetlerin finansmanının Beveridge Modeli, Bismark Modeli, Karma Model ile Özel Sigorta aracılığıyla sağlamasına göre dört temel kategoriye ayrılabilir. Beveridge Modelinde finansmanın temeli vergiler aracılığıyla, Bismark Modelinde ise kamu sigorta sistemi aracılığıyla sağlanmaktadır (12).

\section{TEMEL SAĞLIK HIZMETLERI VE BIRINCi BASAMAK HIZMETLERIN GENEL ÇERÇEVESi}

Dünya Sağlık Örgütü (DSÖ)'nün 2008 yılı raporunda Primary Health Care (PHC)'i bir reformlar paketi olarak tanımlamış ve bu reformları 4 başlık altında açıklamıştır. Evrensel kapsama reformları ile sağlık hizmetlerinde eşitliği, sosyal adaleti ve dışlanmanın sona erdirilmesi amaçlanmıştır. Bu hedeflere ulaşabilmek için sorunun temeline inilmesi gerektiği görüşü özellikle belirtilmiş; siyasi ve teknik tercihlerle toplumsal tepki verilmesi vurgulanmıştır. Bu nedenle herkesin ihtiyaç duyduğu tüm hizmetlere sigorta rejimi aracılığıyla ekstra bir ücret ödemeksizin ulaşmasının sağlanması gerekmektedir.

İkinci başlık olarak, hizmet sunum reformları aracılığıyla bireylerin artan beklentilerini ve intiyaçlarını karşılamak üzere sistemin re-organize edilmesi gerektiği aktarılmış ve bundan dolayı insanların tüm yaşam dönemleri boyunca multidisipliner ekipler eliyle sürekli ve bütüncül olarak diğer sektörlerle işbirliğiyle birlikte sosyal hizmetlerin eklenmesiyle hedeflerin gerçekleşebileceği belirtilmiştir. Bireylerin sağlık sorunlarıyla başa çıkarak sağlıklı yaşama kavuşabilmesi, hükümetlerin şehirleşme, iklim değişikliği, cinsiyet ayrımcılığı ve sınıfsal koşullarından dolayı ortaya çıkabile- 
cek sorunlara bağlı olduğu vurgulanmış ve üçüncü başlık olarak kamu politika reformları anlatılmışıı. Bu politikalarla öncelikli sağlık sorunları ele alınmakla birlikte sağlığı koruma, geliştirme ve risk faktörlerinin ortadan kaldırılması gibi halk sağlığı hizmetlerinin de önemi vurgulanmıştır. Kamusal reformlar bununla sınırlı kalmayarak sağlık sisteminin geliştirilmesi için ilaç, teknoloji, insan kaynağı ve finansman gibi sistemin geneliyle ilgili atılacak adımları da kapsamaktadır. Ayrıca sağlık dışındaki sektörler tarafından geliştirilen politikalar ile toplum sağıı̆ının yükseltilebileceği gerçeğinden hareketle, sektörler arası işbirliğine yönelik bilinçli çabaların artırıması hedeflenmiştir (13).

Birinci basamak sağlık hizmeti (BBSH), halkın sağlığının yararına koordine edilmiş hizmetlerin erişiminin ve kullanımının kolaylaştırılmasına özel olarak odaklanan genel sağlık bakım sisteminin bir alt sistemi olarak düşünülebilir (14). Türkiye Cumhuriyeti'nde BBSH, Aile Sağlığı Merkezleri, Toplum Sağlığı Merkezleri ve Verem Savaş Dispanserleri (VSD), Çocuk, Ergen, Kadın ve Üreme Sağığı (ÇEKÜS) ve Kanser Erken Teşhis, Tarama ve Eğitim Merkezi (KETEM) aracılığıyla yürütülen ve Genel Sağlık Sigortası kapsamında olan tüm ülke vatandaşlarının hizmet alımı sırasında muayene katıım ücreti ödemediği ücretsiz verilen bir hizmet türüdür.

\section{TÜRKIYE VE ISPANYA GENEL ÖZELLIKLERI VE SAĞLIK SISTEMLERI}

\section{Türkiye Cumhuriyeti Genel Özellikleri}

\section{Politik ve Siyasi Yapı}

Türkiye Cumhuriyeti, Anayasasında sosyal bir hukuk devleti olarak tanımlanmaktadır. Dili Türkçe, para birimi Türk Lirası ve başkenti Ankara'dır. Ülkede yasama, yürütme ve yargı şeklinde kuvvetler ayrımı uygulanır. Yasama yetkisi Türkiye Büyük Millet Meclisi'nindir. Yürütme yetkisi ve görevi, Cumhurbaşkanı tarafından kullanılır. Yargı ise bağımsız ve tarafsız mahkemeler tarafından sağlanır (15).

Yüzölçümü 814.578 km²'dir. Türkiye'nin en büyük idari birimleri illerdir. Toplam 81 il, 922 ilçe, 32044 mahalle ve 18335 köy mevcuttur (16).

\section{Demografik Yapı}

Türkiye İstatistik Kurumu'nun (TÜiK) Şubat 2018 tarihinde yayınladığı 27587 sayılı bültene göre; ülke nüfusu 80 milyon 810 bin 525'dir. Nüfusun \%50,2'si erkektir. Ortanca yaş önceki yıla göre yükselerek 31,7 olmuştur. Belde ve köylerde hayatlarını sürdürenlerin oranı yalnızca $\% 7,5^{\prime}$ tir (17). TÜiK 30567 sayılı haber bültenine göre 2040 senesine gelindiğinde ülke nüfusunun 100 milyondan fazla olması öngörülmektedir. Ayrıca nüfus yaşlanmasının devam edeceği ve yaşı nüfus oranının 2023'te \%10,2,'ye 2040'da ise \%16,3'e yükseleceği beklenmektedir $(18,19)$.

\section{Ekonomi}

Türkiye'nin gayrisafi yurt içi hasılası (GSYH') cari olarak 850,7 milyar dolardır. TÜIK'in 33671 sayılı bültenine göre kişi başına GSYH 2019 senesinde cari fiyatlarla 52 bin 316 TL, ABD doları cinsinden 9 bin 213 dolardır. Gini katsayısı Türkiye'de aynı yıl için 0,395 'tir ve ülke içerisinde $(0,281$ 0,428 ) değişmektedir. P80/P20 oranı ise 7,4'tür. Bölgeler arasında farklılaşmaktadır (7,8 ile 4,2). Bu veriler ülke içerisindeki eşitsizliği yansıtması açısından dikkate değerdir $(20,21)$.

TÜiK Eylül 2020 tarihinde yayınladığı 33790 sayılı bültene göre ise ülkemizdeki işsizlik oranı $\% 13,4$ seviyesinde gerçekleşmiştir. Genç işsizlik oranı \%26,1, İstihdam oranı \%42,4 olarak saptanırken kayıt dışı çalışanların oranı $\% 31,3$ olarak ölçülmüştür. İşgücüne katılma oranı erkeklerde $\% 67,6$, kadınlarda ise $\% 30,8$ olarak gerçekleştiği belirtmektedir. Gençler arasında ne eğitimde ne de istihdamda olanların oranı ise \% 29,3 'tür (21).

\section{Eğitim}

Türkiye'de tüm vatandaşlar için zorunlu olan 12 yıllık eğitim, üç kademeli olarak sunulmaktadır. Birinci kademe dört yıl süreli ilkokul (1. 2. 3. ve 4. sınıf), ikinci kademe dört yıl süreli ortaokul (5. 6. 7. ve 8. sınıf) ve üçüncü kademe dört yıl süreli lise (9. 10. 11. ve 12. sınıf) olarak düzenlenmiştir (22).

The Organisatıon For Economic Co-Operation And Development (OECD) 2019 Türkiye raporuna göre; Genç yetişkinlerin büyük bir kısmı ortaöğretim seviyesinin altındadır (\%43). Türkiye'de üç yaş altındaki her 1000 çocuktan sadece üçü $(\% 0,3)$ erken çocukluk eğitimi ve bakım hizmetlerinden faydalanmaktadır. 2017 yılında Türkiye, tam zamanlı öğrenci başına toplam 5.586 ABD Doları harcama yapmıştır. Türkiye'de eğitime GSYiH'nin \%5'i ayrılmaktadır (23).

\section{Türkiye Sağlık Sisteminin Evrimsel Süreci ve Genel Görünüşü}

TC Sağlık Bakanlığı, 3 Mayıs 1920'de TBMM'nin açılışının hemen ardından 3 sayılı Kanun ile kurulmuştur. Öncelikli hedef savaş sonrası sorunların çözülmesi ve mevzuat çalışmaları ile koruyucu sağlık hizmetlerinin sağlanması olmuştur. Koruyucu sağlık hizmetleri devlet sorumluluğunda sunulmuş, tedavi edici hizmetler ise yerel yönetimlere bırakıımışıı. 1923 verilerine göz attığımızda sağlık hizmet altyapısının ve insan kaynaklarının yetersizliği açıkça fark edilmektedir (24-26).

Sosyal Sigortalar Kurumunun (SSK) çekirdeği olarak adlandırılabilecek İşçi Sigortaları Kurumu 1945 yılında kurulmuştur. 1950 yııında Emekli Sandığı Kanununun çıkarılması, 1952 senesinde ise anne ve çocukların sağlığı için uzmanlaşmış kurumların oluşturulması ve bazı sağlık meslek birliklerinin faaliyetlerine başlamaları bu yılların dikkate değer gelişmelerindendir $(24,26)$. 
1961 Anayasası ile sağlık temel bir insan hakkı olarak görülmüştür. Sağılk hakkı başlığı taşıyan 49. maddede devlet bu hakkın sağlanmasından sorumlu tutulmuştur $(27,28)$. Anayasanın 129. maddesi ile planlı ekonomi modeli için hukuki zemin oluşturulmuş ve sağlık hizmetleri başlatılan kalkınma planları içerisinde yer almıştır. İlk kalkınma planında sağlık konusu ile ilgili ana hedef olarak vatandaşların sağlık seviyesinin arttırılması amaçlanmıştır. Bu nedenle halk sağlığı hizmetlerinin ön plana alınması kararlaştırılmıştır. Belirlenen gayenin başarılması için 224 sayılı Kanun çıkarılmış ve bu kanun ile koruyucu hizmetlerin ön plana alındığı, ülkenin en ücra köşelerine değin ulaşabilecek bir hizmet ağının inşa edilmesi amaçlanmıştır $(27,28)$.

İlgili süreç devam ederken kapitalist dünyada 20. yy' In son çeyreğinde yaşanan ekonomik kriz tüm ülkeleri olduğu gibi Türkiye'yi de derinden etkilemiştir. Krizden çıkış yolu olarak görülen neoliberal ekonomi-politik zaman içerisinde egemen dünya görüşü hâline gelmiştir. Sosyal devlet paradigmasının etkisini yitirmeye başlaması ile birlikte neoliberalizmin baskın etkisi sağlık sektöründe de kendisini göstermiş, değişim rüzgarının esmesinde asıl itici gücü oluşturmuştur. Bununla birlikte sağlıkta reform gerekçeleri olarak hizmetlerde gün geçtikçe yoğun olarak kullanılan teknolojinin maliyetleri yükselttiği dolayısıyla finansman kaynaklarının yetersiz kaldığı ayrıca hizmetlerin verimsiz ve etkisiz sunulması gösterilmiştir.

1980'li yıllarda başlayan mevcut süreçte birçok kez reform çabaları gündeme gelmiş fakat istenilen sonuçlara ulaşılamamıştır. Son reform paketi 2003 yılı Sağlıkta Dönüşüm Programı (SDP) adı ile başlatılmış ve tam manasıyla uygulanmaya konulabilmiştir. SDP, 8 ana başlıkla başlayıp, günümüzde 2007 yılında 3 yeni başsığın ilave edilmesiyle devam edilmektedir. Bu dönemde farklı sigorta rejimleri olan SSK, Bağ-Kur ve Emekli Sandığı Sosyal Güvenlik Kurumu (SGK) çatısı altında birleştirilmiş, Genel Sağlık Sigortası (GSS) kurularak tüm vatandaşlar kapsama dahil edilerek, temel teminat paketiyle tek tip hizmet verilmeye başlanmıştır. Sağlık Ocakları temelinde sürdürülen BBSH, Aile Hekimliği Modeli merkeze alınarak dönüşüme uğramıştır. Bölge temelli, sevk zinciri esasına dayalı entegre hizmetlerin sunulduğu Sağılk Ocakları yapılanmasından, her ailenin bir bütün olduğu, aile bireylerinin yaş ve hastalık gözetmeksizin birlikte incelenmesine odaklanan Aile Hekimi ve Aile Sağlığı Çalışanı olarak iki kişilik bir ekiple hizmet sunulan Aile Hekimliği Modeline geçilmiştir. Bu modelde hekimlere girişimci ve yönetici rolleri yüklenmiştir. Ekip üyelerinin sözleşme esaslı çalışığı ve performansa dayalı ücretlendirildiği Aile Hekimliği Modelinde kişilere hekim seçme hakkı da tanınmıştır.

SB'da Anayasa'da çizilen çerçeve içerisinde hizmet standartlarının belirlenip denetlenmesi ile sınırlandırımaya çaIışı|mışır (29-33).
Ülkemizde birinci ve ikinci basamak sağlık hizmetlerinin ana sağlayıcısı Sağlık Bakanlığı'dır. Merkezi düzeyde birinci basamak sağlık hizmetleri ile halk sağlığı hizmetleri 2003 senesinde başlatılan SDP çerçevesinde şekillenmiştir. Sağlık hizmetlerinin sunumu kamu ve özel sektör ile vakıf, dernek ve üniversiteler tarafından sağlanmaktadır. Ülkemizde birinci basamak hizmetler, Aile Hekimlikleri (AHM) ve Toplum Sağlığı Merkezleri (TSM) ile TSM'lerinin ilgili birimleri aracılığıyla sunulmaktadır $(34,35)$.

Sınıflandırma kriteri olarak finansman kaynaklarının kullanımı dikkate alındığında SDP öncesinde Beveridge Modeli çerçevesinde değerlendirilen ülkemiz, günümüzde Bismark Modeli içerisinde yer almaktadır. Sağık hizmetlerinin finansmanının sağlanmasında SGK ile birlikte, Hazine ve Maliye Bakanlığı, özel ve tamamlayıcı sağlık sigorta kuruluşları ile kişilerin hizmet kullanımlarında yaptıkları kişisel ödemelerin olduğu görülmektedir. 2015 yılı toplam sağlık harcamalarının ağırıklı hangi kaynaklardan sağlandığını incelediğimizde (\%53.4) SGK'nın önce geldiği sonrasında sırasıyla genel vergi kaynakları ile kişisel harcamaların olduğu görülmektedir. (\%25.1) ile (\%.16.5). SDP öncesinde ana finansman kaynağının sigorta primlerinin olduğu görülmektedir (\%30.1 ile vergiler, \%40.6 ile Sosyal Güvenlik Kurumları Toplamı) $(29,32)$. Sevk zincirinin yasal zorunluluk olmamasıyla birlikte ekonomik araçlar kullanılarak vatandaşların sevk zincirine dahil olması sağlanmaya çalışımaktadır. Vatandaşlara istedikleri sağlık kuruluşunu seçme hakkı verilmekle birlikte bu hakkı kullanmaları basamaklara göre belirlenmiş muayene katılım paylarını ödemeleriyle mümkündür. Sevk zinciri içerisinde üst kategorideki kurumlara gittiklerinde ise bahsedilen ücretlerden muaf olacaklardır.

\section{İspanya Genel Özellikleri}

\section{Politik ve Siyasi Yapı}

İspanya'nın resmi adı İspanya Krallığı'dır. Ülke Avrupa'nın güneybatısında, iber Yarımadası'nda yer almaktadır. 505 $955 \mathrm{~km}^{2}$ ile dünyanın 52. Avrupa'nın ise 4 . büyük ülkesidir. 1978 Anayasası, İspanya'nın kurumsal örgütlenmesini belirlemektedir. Ülke demokratik, hukukun üstünlüğünü savunan bir refah devletidir. Sosyal pazar ekonomisi hâkimdir. Başkenti ise Madrid' tir (36).

Nüfusunun büyük çoğunluğu (\%80) İspanyolca konuşmaktadır. Ayrıca (\%15-18) Katalanca ve Galik dili, Baskça ile Aranca' da konuşulmaktadır. Para Birimi Euro (€)'dur. Ülke Parlamenter monarşi ile yönetilir. Kral devletin başı ve silahlı kuvvetlerin başkomutanıdır. Yürütme yetkisi, hükümet tarafından uygulanır. Yürütme gücünün başında Başbakan bulunur. Başbakan, çoğunluğu sağlayan partinin önerisiyle Kral tarafından atanır. Yasama yetkisi, Temsilciler Meclisi ve Senato tarafından oluşturulan iki meclisli bir organ olan Cortes Generales tarafından yürütülür. Yargı, yürütme ve yasama organından bağımsız olarak Kral adına mahke- 
melerce sağlanır. Benzer bir örgütlenme sistemini izleyen özerk bölgelerdeki yargı organları da ülkenin en üst yargı mercii olan Yüksek Mahkeme'nin denetimine bağlıdır. İspanya idari olarak genişletilmiş güçlere sahip 17 Özerk Topluluk (bölge) ile iki özerk şehirden oluşmaktadır. Ayrıca 52 il ve 8000 'den fazla belediye bulunmaktadır. Her bir özerk topluluğun ve özerk kentin hükümet biçimi de, parlamenter sisteme dayanmaktadır $(3,37)$.

\section{Demografik Yapı}

İspanya nüfusu 2018 yılı itibariyle 46.733.038 kişidir. Erkek/ Kadın oranında baktığımızda yaklaşık \%51 ile kadın nüfusunun üstünlüğü bulunmaktadır. 2018 yılında ülkede toplam doğum rakamı 410,583 iken ölümler 410.611 olduğu görülmektedir. Ülkedeki yabancıların nüfusa oranı yaklaşık \%10'dur (4.663.726 kişi). Yabancı göçmenler nüfus hareketliliği üzerinde önemli etkisi bulunun bir unsur olarak dikkat çekicidir (38). Gelecekteki nüfus projeksiyonu toplam nüfusun 2032/2033 senesinde 49 milyona yükseleceğinin, 2067/2068 yıllarında ise 48,5 milyon kişiye düşeceği beklenmektedir. Demografik verilerinin ayrıntılarına baktığımızda evlilik oranının, doğurganlığın ve kadın başına düşen çocuk sayısının düştüğünü fakat ölüm oranının artığını dolayısıyla nüfus artış hızının azaldığı gözlenmektedir (39).

\section{Ekonomi}

Çeşitli müdahaleci politikalar uygulayan devletin ekonomi üzerinde önemli bir ağırlığı vardır. Kişi başına GSYiH 2017 Yılı 39627 ABD Dolarıdır. Reel GSYiH büyümesinin \% 3,0 olduğu İspanya' da Kamu Yönetiminin ülke ekonomisine katkısı \% 18 ile ağırlıklı olarak savunma, eğitim, sağlık ve sosyal hizmetler alanlarındadır. Devlet 2017 yılı verilerine göre sağlıkla ilgili GSYiH'nın \%6,3 oranında harcama yapmaktadır. Ülkede işsizlik oranı (2017 yılı) \% 17,2 olarak ölçülmüştür. İspanya'nın sanayi sektörleri ülkenin GSMH'sinin yaklaşık \% 23,6'sine katkıda bulunurken, hizmet sektörü İspanya'nın toplam üretiminin \% 73,8'ini oluşturmakta tarım ise yaklaşık \% 2,6 oranında katkıda bulunmaktadır (40). Ülke \%15 dolaylarındaki sendikalaşma oranıyla Avrupa'daki en düşük düzeyli ülkeleri arasında yer almaktadır (41).

Yoksulluk oranı 2016 Yılı verilerine göre (Yoksulluk veya sosyal dışlanma riski taşıyan insanlar, toplam nüfusun \% 'si olarak yaş ve cinsiyete göre) \% 27,9, (37) göreceli (2015 Yılı) yoksulluk oranı ise \% 15,9 olarak bulunmuştur (40). Ülkenin Gini Katsayısı 0,345; P80/P20 oranı ise 6.5'tir (42, 43).

İspanya 1986 'da AB'ye katılmıştır ve uzun bir süre büyüme trendi içerisinde olmuştur. Aynı zamanda Birleşmiş Milletler, OECD, Avrupa Ekonomik Anlaşması (EEA), Dünya Ticaret Örgütü (DTÖ), Kuzey Atlantik Antlaşması Örgütü (NATO) ve Avrupa Konseyi gibi diğer uluslararası kuruluşlara da üyedir. Sağık sektörü ile doğrudan ilgili GATT, Çocuk HakIarına Dair Sözleşme, Avrupa İnsan Hakları Sözleşmesi ve
Uluslararası İnsan Hakları Sözleşmesi gibi sözleşmelere de imza atmıştır.

\section{Eğitim}

Eğitim, 6 ila 16 yaş arasındaki tüm çocuklar için zorunlu ve ücretsiz olup; ülkenin 17 özerk toplumunun hükümetleri ile birlikte Ulusal hükümet tarafından desteklenmektedir. Orta öğretim aşamasında bir sınıftaki ortalama öğrenci sayısı İspanyol okullarında yaklaşık 30'dur. Ülkede okur-yazarlık oranı \%98 civarındadır. 5 Yaş çocuklarının 2015 yılı verilerine göre okullaşma oranı \%98,1 'tir (44). Eğitim sisteminin kalitesi açısından değerlendirildiğinde, AÇıILIMI (PISA) okuma yazma, matematik ve fen bilimlerinde ortalama 491 Puan alınarak 486 olan OECD ortalamasından yüksektir. İspanya'da, 25-64 yaş grubundaki yetişkinlerin\% 58'i, ortaöğretimi tamamlamıştır. OECD ortalaması ise $\% 74$ 'dür. Yükseköğretime girenler arasında kadınların payı \%52.7 iken Yükseköğrenim gören kadınlar \%38.2 olarak saptanmıştır. İspanya okul öncesi eğitime öğrenci başına 6977 ABD Doları harcamaktadır. GSYIH'nın \%1.3'ü primer eğitime ayrılmaktadır (23).

\section{İspanya Sağlık Sisteminin Evrimsel Süreci ve Genel Görünüşü}

Ülkenin diktatörlük döneminde sosyal güvenlik programına dayalı olan merkezileşmiş sağlık sistemi söz konusuyken 1978 senesinde kabul edilen yeni Anayasa bütün vatandaşların sağlığının korunması hakkına kavuşmasını sağlamış ve genel vergilerle finanse edilen evrensel kapsama sağlayan bir modele geçiş yapmıştır. Bununla birlikte bölgesel organizasyona dayalı yeni bir örgütsel çerçeve oluşturulmuştur. 1978 ve 1981 senelerinde sırasıyla Ulusal Sağlık Enstitüsü ile Sağlık Bakanlığı yapılandırılmıştır. Sistem 1986 yılında çıkarılan Genel Sağılı Kanunu çerçevesinde tasarlanmıştır. Bu yasa ile ücretsiz erişim ile evrensel kapsamanın sağlanması hedeflenmiştir. İspanya Anayasanın kabulünden itibaren sağılk sistemi önemli değişimler geçirmiştir. En önemli gelişme sistemin 1986 yılından başlamak üzere sosyal güvenlik rejiminden (Bismark Modeli) ulusal sağlık hizmetlerine (Beveridge Modeli) evrilmesi ve bölgelere desantralizasyon sürecinin yaşanmasıdır (45).

Günümüzde İspanya ulusal koordinasyon altında ama merkezi olmayan bir sağlık sistemine sahiptir. İspanyol Ulusal Sağlık Sistemi vergilerle finanse edilir ve ağırlıklı olarak kamu sağlayıcıları ağı aracılığıyla sunulur. Merkezileştirilmiş bir mevzuat modelinden 25 yıllık bir geçiş sürecinden sonra sağlık yetkileri 2002 yılı sonundan itibaren bölgesel seviyeye devredilmiştir. Bu yetki devri ile bölgelerindeki sağlık hizmetlerinin organizasyonu ve dağıtımıyla ilgili temel yargı yetkisi olan 17 bölgesel Sağık Bakanlığı oluşturulmuştur. Sağlık hizmetlerinin planlanması, sunulması ve harcamaları esas olarak bölgesel yönetimler tarafından belirlenmeye başlanmışıtır. Bu gelişme ülke içerisinde farklı 
modellerin oluşmasına neden olmuştur. Bundan dolayı sistemdeki iki ana aktör olan İspanya Sağlık ve Sosyal Politikalar Bakanlığı ile 17 Bölgesel Sağlık Bakanlığı'nın eşgüdümünü sağlamak üzere Ulusal Koordinasyon Kurulu (CISNS) kurulmuştur. CISNS en yüksek hiyerarşi seviyesindeki idari organdır (45). 2003'ten itibaren CISNS merkezi Sağlık Bakanı ve bölgesel düzeyde sağlık sorunlarından sorumlu 17 bakan ile iki daimi gözlemciden oluşmaktadır. Bu koordinasyon kurulunda sistemin planlanması, değerlendirilmesi ve koordinasyonu ile ilgili önemli konularda tavsiye niteliğinde kararlar alınmaktadır. İspanya Sağlık ve Sosyal Politikalar Bakanlığı (MSSI) temel olarak sistem için Bölgelerarası Konseyi'nin yardımıyla yönetim ve koordinasyon işlevini yerine getirmektedir. Bunun yanı sıra yasal altyapının oluşturulmasında kilit roldedir. Bakanlık yakın zamanda sosyal hizmetler ve bağımlılık bakımı alanında ulusal otorite olmuştur. Sorumlulukları; temel olarak sosyal dayanışma, toplumsal kapsayıcılık, aile ve çocuk koruma politikaları çerçevesine denk düşmektedir (fiili yönetim yetkinlikleri ve bu hizmetlerin sağlanması bölgesel ve bazen yerel düzeylere aktarılmaktadır). Bakanlık ayrıca Ceuta ve Melilla Özerk Şehirlerinin sağlık bakımını, Sağlık Yönetimi Enstitüsü olarak adlandırılan merkezi olarak yönetilen bir kurum aracılığıyla finanse eder ve yönetir (37). Merkezi hükümetin çeşitli organları sisteme katkı sağlayan diğer kurumlardır. 2004'den 2010'a kadar sistem ademi-merkeziyet süreci, çeşitli kanunlarda ile derinleşmiştir. Böylece Özerk Bölgelerin refah hizmetlerine daha fazla kaynak ayırmalarına ve gelirleri artırmalarına izin verilmiş, kısmi olarak vergilendirme konusundaki düzenleme kapasitelerini ve bir dereceye kadar dolaylı vergilerin bir kısmını devralmıştır. Sonuç olarak Özerk Bölgeler, sağlık bakım ağını, hizmet tedarikini ve işgücü kapasitesini genişletebilmiştir. Bunların yanı sıra merkezi planlama yetkililerinin yetki alanlarını daraltma gerçekleştirilmiştir. Yeni mevzuat bu tarihten itibaren sağlık sisteminin sürdürülebilirliğine eğilmiştir. Özerk Bölgelerde ana aktörler, genellikle Sağlık Hizmetleri sunumunu yönetmeyi amaçlayan uzmanlaşmış kurumlar tarafından desteklenen Sağlık Bakanlığı'dır. Bazı Özerk Bölgeler, ulusal bir ağda organize edilen bir sağlık teknolojisi değerlendirme kuruluşunun varlığından da yararlanır $(37,45)$.

Özel sektör ise İspanyol sağlık sisteminde önemli bir oyuncusudur ve bireylere gönüllü sağlık sigortası düzenlemektedir. Beş İspanyol vatandaşından biri, evrensel zorunlu devlet sigortasına ek olarak gönüllü bir sağlık sigortası planına sahiptir. İspanya'da gönüllü sağlık sigortası kanuni sistemden bağımsızdır ve (ek) tamamlayıcıdır. Gönüllü Sağlık Sigorta planı Özerk Bölgelerde çok sayıda değişiklik ve farklılıklar olsa da yıllardır satın alanlar için mali avantajları vardır. Son yıllarda İspanya'daki sigorta pazarı artış eğilimi göstermektedir. Ulusal sağlık sisteminin kapsamadığı diş bakımı ve optik bakımı sağlamaktadır ve özellikle hastane ve ilaç bakım hizmetlerinde kamu sektörü ile yakından ilişkilidir (37).
Ulusal sağlık hizmetinin sağlanmasında ana finansman kaynağı genel vergilerdir. Bu yol ile kamu kaynaklarının \%94,5’i finanse edilmektedir. Buna karşılık, memurlar, Silahlı Kuvvetler ve yargı (MUFACE, MUGEJU ve ISFAS) için hizmet veren sigorta rejimi, bordro katkıları ve vergilendirmenin bir karışımından finanse edilir ve kaynakların \%3,4'ünü oluşturmaktadır. Öte yandan bordro ve işverenlerin katkıları ile oluşturulan sağlık fonlarının sistemin finansmanına katkısı $\% 2,1$ 'e karşılık gelmektedir. Sistemin nüfus kapsamı ise $\% 99,5$ 'tir ve sistem tüm vatandaşlar için kapsamlı bir temel teminat paketini garanti etmektedir. Hizmetler herkes için ücretsizdir. Çeşitli harcamalar için örneğin ilaç katılım payı gibi cepten ödeme yapmak gerekebilir. İspanya'da sağlık harcamaları 2009 yılına kadar uluslararası artış eğilimini sürdürmüştür. $\mathrm{O}$ zamandan bu yana, hem kişi başına harcama hem de GSYIH payı olarak eğilim tersine dönmüştür. 2017 yılında, kişi başına ABD doları cinsinden satın alma gücü paritesi baz alınarak yapılan cari harcamalara baktığımızda 3248 Dolar ile 4003 Dolar olan OECD ortalamasının altında olduğu görülmektedir. İspanya'da sağlık harcaması, 2017 yılında GSYIH' nın \% 8,8'sini oluştururken, OECD ortalamasının $(\% 8,9)$ ' çok az altındadır. İspanya'daki sağlık harcamalarının yaklaşık \% 70,8'i (OECD ortalaması \%73,5) kamu tarafından finanse edilmektedir $(3,8)$.

\section{TÜRKIYE VE ISPANYA BIRINCI BASAMAK SAĞLIK HIZMETLERININ KARŞILAŞTIRILMASI}

\section{Araştırmanın Kısıtları}

Ülke karşılaştırması yapılan araştırmada bazı kısıtlılıklar mevcuttur. Ülkelerin sağlık çıktılarının ölçülmesindeki çeşitli zorluklar, elde edilen verilerin yetersizliği ile farklı metotlarla toplanmış olma olasılığı en önemli kısıttır $(6,10)$. Ayrıca her ülkenin kendi özelliklerine göre şekillendirildiği bir sisteminin var olması ve ülke içerisinde yer alan özerk yönetimler aracılığıyla farklı organizasyon ile gelir sağlama yöntemlerinin mevcut olması da ikinci bir kısıttır (10). Bunun yanı sıra bu çalışmada WHO'nun kullandığı gösterge kriterleri kullanılmıştır. Bu kriterler sadece BBSH ile ilgili değildir. Genel sağlık sistemlerinin performans karşılaştırmasında kullanılması daha yararlı olacaktır (46).

Birinci Basamak Sağlık Hizmetlerinin finansman kaynaklarını incelediğimizde büyük bir oranla kamunun ağırlığının olduğunu görmemize rağmen bu hizmet türü içerisinde yer alan Aile Hekimliği ve kamu/özel/cepten finansman oranı ile ilgili veri bulunmamaktadır. Ayrıca Aile Hekimi temelinde şekillenen birinci basamak hizmetlerinin tüm birimlerinde koruyucu /tedavi edici hizmetlere ne kadar kaynak ayrıldığı ile ilgili veri de bulunmamaktadır.

\section{Araştırma Yöntemi}

Araştırma yöntemi olarak betimsel kıyaslamalara dayalı karşılaştırmalı analiz yapılmıştır. Türkiye ve İspanya, yöne- 
tişim, sağlık ekonomisi, sağlık hizmetlerinin kullanımı ve insan kaynakları bakımından kıyaslanmıştır. Ayrıca gösterge olarak seçilen WHO'nun Global Reference List of 100 Core Health Indicators kriterlerine göre yıllar bazında kıyaslama yapılmıştır (46).

Kriterler kıyaslandığında, İspanya'nın ulusal sağlık sistemine sahip olduğu ve birinci basamak sağlık hizmetlerinin finansmanının vergilerle sağlandığı, birinci basamak sağlık harcamalarının toplam sağlık harcamaları içinde yüksek bir paya sahip olduğu, uzman hekimlere ulaşabilmek için aile hekimi tarafından sevk zincirinin etkin olduğu, Türkiye'nin ise sağlık hizmetlerinin finansmanının primlerle sağlandığı, uzman hekimlere ulaşabilmek için aile hekimi tarafından sevk zincirinin zorunlu olmadığı görülmüştür.
Tablo 1'deki verilere göre sağlıklı bir hayat için üzerinde çaIışılması gereken yaşam koşullarının olduğu görülmektedir. Bunlar arasında ülkemizde hava kalitesinin ve kanalizasyon şebeke yeterliliğinin İspanya'nın gerisinde olduğu tespit edilmiştir. Bunun yanı sıra, koruyucu sağlık hizmetlerinin etkinliğini gösteren en önemli kriterlerden biri olan anne ve beş yaş altı ölüm oranları ile ilgili veriler incelendiğinde ise ülkemizin İspanya'dan yaklaşık üç kat daha yüksek oranlara sahip olduğu görülmektedir. Bununla birlikte, koruyucu sağIık hizmetlerinin önemli göstergelerinden olan bağışıklama oranlarına bakıldığında, ülkemiz ile İspanya'ya ait verilerin birbirine yakın olduğu tespit edilmiştir. Son olarak profesyonel sağlık personelleri ile ilgili veriler incelendiğinde ise İspanya'nın ülkemizden yaklaşık olarak iki kat daha iyi durumda olduğu saptanmıştır.

Tablo 1: Türkiye ile İspanya'nın Sağlık Göstergelerinin Karşılaştırılması (46)

\begin{tabular}{|c|c|c|c|}
\hline Gösterge* $^{*}$ & YII & Türkiye & İspanya \\
\hline Trafik kazası nedeniyle ölüm oranı (100 000 kişi başına) & 2013 & 8.9 & 3.7 \\
\hline Anne ölümleri oranı (100.000 canlı doğumda) & 2015 & 16 & 5 \\
\hline Güvenli şekilde yönetilen içme suyu servislerini kullanan nüfusun oranı (\%) & 2015 & Veri Yok & 98 \\
\hline Doğuşta beklenen yaşam süresi & 2016 & 79.4 & 83.1 \\
\hline Doğumda sağlıklı yaşam beklentisi & 2016 & 66,0 & 73,8 \\
\hline Beş yaş altı ölüm oranı (1000 canlı doğumda) & 2016 & 12,7 & 3.3 \\
\hline Yenidoğan ölüm oranı (1000 canlı doğumda) & 2016 & 6.5 & 2.0 \\
\hline Tüberküloz insidansı (100.000 nüfusta) & 2016 & 18 & 10 \\
\hline Bulaşıcı olmayan hastalıklara bağlı ölüm (\%) & 2016 & 16.1 & 9.9 \\
\hline İntihar ölüm oranı (100 000 kişi için) & 2016 & 7.3 & 8.7 \\
\hline Kişi başına toplam alkol (> = 15 yaş) tüketim (litre saf alkol) (\%) & 2016 & 2.0 & 10.0 \\
\hline Ergen doğum oranı (15-19 yaş arası 1000 kadın için) & 2016 & 26.9 & 7.7 \\
\hline İstenmeyen zehirlenmelerden ölüm oranı (100.000 nüfus başına) & 2016 & 0.3 & 0.2 \\
\hline 15 yaş ve üstü kişilerde yaşa göre standartlaştırılmış tütün kullanımı yaygınlığı (\%)Erkek - Kadın & 2016 & $41.1-14.1$ & $31.4-27.4$ \\
\hline (Difteri, Tetanoz Boğmaca) DTP3 1 yaş arasındaki bağışıklama kapsamı (\%) & 2016 & 98 & 97 \\
\hline İkinci dozunu içeren Kızamık aşısı (MCV2) (\%) & 2016 & 85 & 95 \\
\hline Konjuge pnömokok (PCV3)1 yaş arasındaki bağışıklama kapsamı (\%) & 2016 & 98 & Veri Yok \\
\hline 1000 kişi başına düşen hekim sayısı & 2016 & 1.7 & 3.9 \\
\hline 1000 kişi başına düşen hemşire ve ebe sayısı & 2016 & 2.6 & 5.3 \\
\hline 1000 kişi başına düşen diş hekimi sayısı & 2016 & 0.3 & 0.7 \\
\hline 1000 kişi başına düşen eczacı sayısı & 2016 & 0.3 & 1.2 \\
\hline 5 yaşın altındaki çocuklarda kısa boy sıklığı (\%) & 2016 & 9.5 & Veri Yok \\
\hline 5 yaşın altındaki çocuklarda aşırı zayıflık sıklığı (\%) & 2016 & 1.7 & Veri Yok \\
\hline 5 yaşın altındaki çocuklarda aşırı kilo prevalansı (\%) & 2016 & 10.9 & Veri Yok \\
\hline Nitelikli sağlık personelinin katılığı doğumların oranı (\%) & 2017 & 97 & Veri Yok \\
\hline Güvenli şekilde yönetilen kanalizasyon servislerini kullanan nüfusun oranı (\%) & 2017 & 44 & 97 \\
\hline Kentsel alanlarda ( $\mu \mathrm{g} / \mathrm{m} 3)$ yıllık ortalama ince partikül madde konsantrasyonları (PM2.5) & 2017 & 41.2 & 9.8 \\
\hline Ölüm nedeni verilerinin eksiksizliği (\%) & 2017 & 89 & 100 \\
\hline
\end{tabular}




\section{SONUÇ ve TARTIŞMA}

Günümüzde bireylerin en fazla ilgi gösterdikleri konulardan biri sağlıktır. Sağlık yaşamın hemen her alanından doğrudan veya dolaylı olarak etkilenen ve tüm sektörel faaliyetlere olumlu/olumsuz tesir eden, ölçümü ve değerlendirilmesi zor bir olgudur. İnsan sağlığını etkileyen binlerce faktör olduğunu göz önüne aldığımızda, toplumların sağlık düzeyini yükseltebilmek için sadece sağlık hizmetlerine odaklanılıp sağlıklı yaşam koşullarını yaratan sağlığın sosyal determinantlarına yeterince eğilmemek istenilen gayeye ulaşılamamasına neden olmaktadır. Örneğin eğitim süreçlerinin çıktıları, bireylerin ve dolayısıyla toplumların yaşam standartları ile refahlarına etki etmektedir. Literatürde eğitimin bireylerin/toplumların sağlıklılık düzeyine olan etkileri üzerine yapılan çalışmalara sıkça rastlanmaktadır (51-53). Ülkemizde eğitim alanında çeşitli reformlar gerçekleştirilmiş ve sistem değişikliğine gidilmiştir. Ülke insanının eğitim seviyesinin yükseltilmesi ve eğitime ayrılan finansmanın kendi gelişmişlik düzeyindeki ülkelerin seviyesine çıkarılması gerekmektedir. Bunun yanı sıra eğitimde kalitenin artırılması, bilim temeline dayanan müfredatın hazırlanması, fırsat eşitliğinin sağlanması, toplumun tüm kesimlerine eşit şekilde ulaştırılması gibi kriterler referans alınarak sunulması, sosyo-ekonomik çıktıları etkileyecek ve dolayısıyla birey ve toplumun sağlık durumuna olumlu yansıyacaktır. Ayrıca eğitim ile sağlık hizmetlerinin kullanımı ve özellikle koruyucu sağlık hizmetlerine olan talep ile doğrudan ilişkisinin olduğunu gösteren akademik çalışmalar göz önüne alındığında (54) eğitim faktörünün önemi daha iyi anlaşılmaktadır. Ülkenin artan eğitim seviyesi ile koruyucu sağlık hizmetleri daha etkili sunulabilecek ayrıca gereksiz hizmet kullanımı azalacaktır. Ülkemizde zorunlu sevk zinciri uygulamasının olmaması, BBSH'nin kapı tutucu işlevi tam anlamıla yerine getirmesini engellemektedir. Tablo 2'deki verilere göre ülkemizde bölgeler arası önemli farklılıklar olmasına rağmen (1.7-3.3) BBSH'ne kişi başına 2,7 başvuru gerçekleşmiştir. Sevk zinciri zorunluluğu olmamasına rağmen BBSH'ne olan talebin yıllar içerisinde artması kuşkusuz önemli olmakla birlikte ikinci ve üçüncü basamak sağlık hizmetlerine olan yoğun başvuru halen sürmektedir. Bu durumda Aile Hekimliği Modelinin temel amacı olan hastalıkların birinci basamakta tespit edilmesi ve üst basamaklarda gereksiz yığıımaların önlenmesi hedefinin gerçekleştirilemediğini göstermektedir. İspanya'da ise ülkemizde olduğu gibi bölgesel farklılıklar olmasına rağmen kişi başına BBSH'ne 5.7 başvuru gerçekleştirilmiştir. Bu yüksek başvurunun temel sebebini zorunlu sevk zinciri uygulamasına bağlayabiliriz. Ayrıca İspanya'da BBSH'de ekip anlayışı ülkemizdeki ekip anlayışından daha geniş ölçekli olarak organize edilmiş ve çeşitli sağlık meslek profesyonelleri ekip içerisine dahil edilmiştir. Bu olgu da kişilerin BBSH'ne olan güvenini yükselttiğini ve dolayısıyla bu basamağa olan talebi de artırdığını düşündürmektedir.
Toplumun sağlığına etki eden bir diğer parametre çevrenin düzenlenmesidir $(55,56)$. Sosyal devlet ilkesinin gereği olarak çevrenin düzenlenmesi, kamu kaynaklarının kullanımıyla gerçekleştirilir. Ülkemizde bu görevin gerçekleştirilmesinde Aile Hekimlerine de görev düşmektedir. Aile Hekimliği Uygulama Yönetmeliği'nde 'Hekimlik uygulaması sırasında karşılaştığı toplum ve çevre sağlığını ilgilendiren durumları bölgesinde bulunduğu toplum sağlığı merkezine bildirmek' ile Aile Hekimlerinin sorumlu tutulduğu görülmektedir (57). Aile hekimlerinin içerisinde yaşadığı toplumun sorunlarına duyarlı olması adına önemli bir adım olarak değerlendirilebilecek bu görevin uygulamada ne kadar gerçekleştirildiği başka bir araştırma konusudur. Sonuç olarak ülkemizde kanalizasyon sistemlerinin, hava kalitesinin ve içme suyu şebekelerinin insan onuruna yakışır bir şekilde gelişmiş ülkelerin seviyesine çıkarılması için gerekli tedbirlerin alınması toplum sağlığı açısından gereklidir.

Etkin bir sağlık sisteminin sahip olması gereken en önemli özelliklerinden biri toplumun geçirdiği demografik değişimlere uyum gösterebilme yeteneğidir. Ülkemizde demografik değişimi yaşayan çok sayıda ülkeden biridir. Örneğin doğumda beklenen yaşam süresi yıllar itibariyle yükselmekte ve kronik hastalıkların görülme sıklığı artmaktadır. Bu nedenle sağlık sisteminin önceliklerinden biri artan kronik hastalıkların risk faktörlerinin belirlenmesi ve gerekli önlemlerin alınması olmalıdır $(57,58)$. SB'da bu nedenle Aile Hekimlerinin, kendisine kayıtlı kişilerin kronik hastalıklarının izlem ve tarama faaliyetlerini gerçekleştirmekle yükümlü tutmuştur (57). Bununla birlikte yaşanan demografik değişim evde bakım hizmetleri gibi hizmet türlerinde de talep artışına neden olacaktır. Dolayısıyla ülkemizde sunulan sağlık hizmetlerinde çeşitliliğe gidilmesi gerekecektir. Ayrıca mevcut sağlık kurumlarının ve görev yapan sağlık profesyonellerinin sayılarının yükseltilmesi gerekmektedir. Böylece hekim başına düşen kişi sayısı azaltılabilecek ve verilecek hizmetlerin nicelik ve nitelik olarak daha iyi bir noktaya ulaşması sağlanabilecektir. Hâli hazırda Aile Hekimi ve Aile Sağlığı Çalışanı sayısı yetersizdir.

Ülkemizdeki sağlık hizmetlerinin finansmanı noktasında önemli sorunların olduğu görülmektedir. Yüksek işsiz olgusu ile kayıt dışı çalışan sayısının toplam istihdamın yaklaşık üçte birini geçmesi önemli sorunlardan birkaçıdır. Bu sorunlar çözülemediği takdirde ülkemiz için sağlık hizmetlerinin ana finansman kaynağı olan sigorta primlerinin eksik toplanmasına veya hiç toplanamamasına, dolayısıyla hizmet finansmanı açısından büyük bir açığın ortaya çıkmasına neden olacaktır. Bu nedenle prim oranlarının belirlenmesi noktasında yoksulluk sınırının insan haysiyetine yakışır düzeyde belirlenip bu sınırın altında olan bireylerin primleri devlet tarafından karşılanması gerekmektedir. Bu noktada yoksulluk ölçeği ülkemiz için yeniden gözden geçirilmelidir. Ayrıca etkin bir maliye politikası oluşturularak kayıt dışı ekonominin 
Tablo 2: Türkiye ile İspanya'nın Birinci Basamak Sağlık Hizmetlerinin Karşılaştırıması (47-50)

\begin{tabular}{|c|c|c|}
\hline Kriterler & İspanya & Türkiye \\
\hline Sağlık Yönetişimi & $\begin{array}{l}\text { * Ulusal Sağlık Sistemine sahiptir. } \\
\text { * BBSH için özel bir bütçe bulunur. } \\
\text { * BB yönetimi ile ilgili sorumluluklar Özerk Bölgelere } \\
\text { devredilmeye devam etmektedir. Özerk Bölgeler BB } \\
\text { için politika geliştirmek, tedarik planlaması yapmak, } \\
\text { finansmanın sağlanması ve hizmetin sunumu ile ilgili } \\
\text { konularda yetki sahibidir. } \\
\text { * Uyulması gereken klinik kılavuzlar mesleki kuruluşlar } \\
\text { ve tıp eğitimi veren eğitim kuruluşları tarafından } \\
\text { geliştirilir. } \\
\text { * Sistem ile ilgili kararlar alınırken paydaşların katılımı } \\
\text { sağlanır. } \\
\text { * BB hizmetlerinin çok disiplinli bakış açısıyla } \\
\text { sağlanması, sağlık eğitimi, temel sağlığın geliştirilmesi } \\
\text { ve önleyici bakım ile ilgili gelecekte ulaşılması } \\
\text { gereken hedefler arasındadır. }\end{array}$ & $\begin{array}{l}\text { * Bismarck Modeli Sağlık Sigortası Sistemi } \\
\text { (Genel Sağlık Sigortası) sistemine sahiptir. } \\
\text { * BBSH için özel bir bütçe bulunur } \\
\text { * Yönetim ile ilgili sorumluluklar kısmen } \\
\text { devredilmiştir. Sağlık Bakanlığı'nın (SB) taşra } \\
\text { teşkilatı olan II Sağlık Müdürlükleri hizmet } \\
\text { sunumu ve tedarik planlaması konularında kimi } \\
\text { yetkilere sahiptir. } \\
\text { * Uyulması gereken klinik kılavuzlar SB } \\
\text { tarafından yayınlanmıştır. } \\
\text { * Sistem ile ilgili kararlara paydaş katılımı vardır. } \\
\text { * Tüm vatandaşların hizmetlere erişiminin } \\
\text { sağlanması, toplum sağlığının yükseltilmesi, } \\
\text { hizmet kalitesinin izlenmesi, çalışanların } \\
\text { görev tanımlarının yapılması, akreditasyon } \\
\text { çalışmalarının artııılması, işgücü kapasitelerinin } \\
\text { geliştirilmesi ile ilgili çalışmalar vardır. }\end{array}$ \\
\hline Sağlık Ekonomisi & $\begin{array}{l}\text { * Toplam sağlık harcaması (TSH) 3371 ABD (\$) (2017) } \\
\text { * Sağlık Harcamalarının GSYIH Payı \%8,8 (2017) } \\
\text { * TSH Finansman Kaynakları Devlet \%66,5 - Sosyal } \\
\text { Sigorta Primleri \%4,8 - Gönüllü Ön Ödeme \%4,6 - } \\
\text { Cepten Ödemeler \%24,1 } \\
\text { * TSH içindeki Birincil Bakım harcamalarındaki Payı } \\
\text { \%17.1 (İspanya Sağlık Bakanlığının veri sisteminde } \\
\text { ise } 2016 \text { Yılı \%13,67) } \\
\text { * Tıbbi harcamalar için sigortasız nüfus yoktur. } \\
\text { * Aile Hekimlerinin \%80’i özerk bölgeler tarafından } \\
\text { istihdam edilmektedir. }\end{array}$ & $\begin{array}{l}\text { * Toplam sağlık harcaması (TSH) } 1194 \text { ABD (\$) } \\
\text { (2017) } \\
\text { * Sağlık harcamalarının GSYï payı \%4,2 } \\
\text { (2017) } \\
\text { * TSH Finansman Kaynakları Devlet \%35,7 } \\
\text { - Sosyal Sigorta Primleri \%42,5 - Cepten } \\
\text { Ödemeler \%21,9 } \\
\text { * TSH içindeki BBSH harcamalarındaki pPayı ile } \\
\text { ilgili bir veri yok } \\
\text { * Tıbbi harcamalar için sigortasız nüfus \%12,7 } \\
\text { * Aile hekimleri Sağlık Bakanlığı ile sözleşme } \\
\text { yaparak çalışmakta, ücretlerini de kendisine } \\
\text { kayıtlı kişi sayısına ve performans kriterlerine } \\
\text { göre almaktadır. }\end{array}$ \\
\hline $\begin{array}{l}\text { Sağlık } \\
\text { Hizmetlerinin } \\
\text { Kullanımı ve İnsan } \\
\text { Kaynakları }\end{array}$ & $\begin{array}{l}\text { * Birincil Bakım Hizmetleri multidisipliner ekipler } \\
\text { ile Temel Sağlık Merkezlerinde verilmektedir. } \\
\text { Planlama kriterlerine bağlı olarak, çocuk doktorları } \\
\text { ve uzman pediatri hemşireleri, fizyoterapistler, diş } \\
\text { hekimleri, psikologlar ve sosyal hizmet uzmanlarıyla } \\
\text { tamamlanabilirler. } \\
\text { * Uzman Aile Hekimi tarafından sevk sistemi } \\
\text { zorunludur. Kapı tutucu işlevi görür. } \\
\text { * Klinik hasta kayıtları rutin olarak tutulur. } \\
\text { * } 13.000 \text { Birinci Bakım Merkezi ve } 2.000 \text { hastane dışı } \\
\text { acil bakım noktası vardır. } \\
\text { * } 233 \text { milyon tıbbi konsültasyon, } 132 \text { milyon } \\
\text { hemşirelik konsültasyonu, } 13 \text { milyon ev ziyareti } \\
\text { gerçekleştirilmiştir. Birey başına } 5.7 \text { (Bölgeler arası } \\
\text { 3,77- 6,82) ziyaret, Çocuk hekimlerine kayıtlı çocuk } \\
\text { başına ortalama } 4,9 \text { (Bölgeler } 3,78 \text { - 5,97) ziyaret } \\
\text { gerçekleşmiştir. Ülke içerisinde bölgeler arasında fark } \\
\text { göze çarpmaktadır. } \\
\text { * Halk sağlığı sisteminin işleyişinde vatandaşların } \\
\text { memnuniyet derecesi 6,68/10 } \\
\text { * OECD’nin yaptığı araştırmalarda sağlığının iyi veya } \\
\text { çok iyi olarak bildiren kişiler \%72,4 }\end{array}$ & $\begin{array}{l}\text { * BBSH Aile Sağlığı Merkezlerinde Aile Hekimi ile } \\
\text { Aile Sağlığı Elemanı tarafından verilmektedir. } \\
\text { * Sevk zinciri zorunlu değildir. } \\
\text { * Klinik hasta kayıtları rutin olarak tutulur. } \\
\text { * } 7980 \text { Aile Sağlığı Merkezi, } 971 \text { Toplum Sağlığı } \\
\text { Merkezi, } 2548 \text { Acil Sağlık İstasyonu vardır. } \\
\text { * Birinci Basamakta } 215 \text { milyon tıbbi } \\
\text { konsültasyon yapılmış ve kişi başı 2,7 başvuru } \\
\text { gerçekleşmiştir. Ülke içerisinde }(1,7-3,3) \text { fark } \\
\text { vardır. } \\
\text { * OECD’nin yaptığı araştırmalarda sağlığının iyi } \\
\text { veya çok iyi olarak bildiren kişiler \%66.4 }\end{array}$ \\
\hline
\end{tabular}


ortadan kaldırılmasına odaklanılması gerekmektedir. İşsiz bireylerin sağlık sigorta primleri de devlet tarafından sisteme aktarılmalıdır. Finansmanla ilgili verilerden İspanya ve Türkiye'nin sağlık hizmetlerinin geneli için bütçelerinden ayırdıkları payları karşılaştırdığımızda İspanya'nın ülkemizden yaklaşık iki kat daha fazla GSYiH'dan sisteme pay ayırdığı görülmektedir. Ayrıca İspanya'nın sağılı hizmetleri için yaptığı kamu harcamalarının ülkemizden daha yüksek olduğu görülmektedir. Son olarak BBSH'de kullanılan bütçe ile ilgili ülkemize ait bir verinin olmaması önemli bir eksikliktir.

BBSH'de görev yapan sağlık çalışanlarının çalışma koşullarını incelediğimizde çeşitli sorunların olduğu görülmektedir. Aile Hekimlerinin ve Aile Sağığı Çalışanlarının hukuki statüsünde var olan muğlaklık (memur/işletmeci/sözleşmeli çalışan vb.) kısa sürede çözülmeli, performans kriterlerinin hizmetlerinin niceliğinin yanı sıra niteliğine de önem verilerek revize edilmesi gerekmektedir. Performans sisteminde en önemli kriterlerin koruyucu hizmetlere verilmesi sistemin başarısı için hayati önemdedir. Hekimlerin girişimci ve yönetici rollerinden arındırılarak asıl görevlerine odaklanmalarının sağlanması, ekip anlayışının geliştirilmesi ve ekip üyelerinin sayısının artırıması hizmet çıktılarına olumlu şekilde yansıyacaktır.

Son olarak hizmet çıktılarının değerlendirmeye alınması noktasında sistem sınırlarının belirlenmesi aşamasındaki belirsizlik kendini göstermiştir. Sağlık çıktıları, eğitim, gelir seviyesi, gelir adaleti, hayvancılık ve tarım gibi alanlardaki gelişmelerden doğrudan/dolaylı olarak etkilenmektedir. Örneğin gelir; temiz içme suyuna erişememe, insan onuruna yakışır konutlarda yaşamını sürdürememe gibi maddi kaynaklara ulaşabilmesini etkilediği gibi eğitim olanakları ve sağlık hizmetleri gibi kamu hizmetlerinden yararlanmasına da etki etmektedir. Annenin gelir yetersizliğinden dolayı yeterli beslenememesi bebeklerin gelişimini olumsuz olarak etkilemektedir (59). Yeterli gelire sahip olamayan bireyler toplumsal tabakaların içinde altlarda yer alırlar ve alt sosyoekonomik tabakada yer alan bireyler daha fazla işsizlik, iş kazası, ve diğer sosyal ve çevresel stresleri yaşarlar ve daha sinik olarak düşmanca veya kaderci bir görünüme sahiptirler. Dolayısıyla bu durumda sağlıksız deneyimler, sosyal dışlanma ve stresi daha çok tecrübe ederler ve sonuç olarak daha sağılıksız bir yaşam sürdürürler (60).

Gelir eşitsizliği toplumsal tabakalaşma açısından bireylerin statüsünü düşürerek çeşitli ruhsal rahatsılııklarında oluşmasına etki eden bir faktör olarak kabul edilmektedir. Nüfus düzeyinde, daha az eşit gelir dağııımına sahip olan toplumlar, daha eşit bir gelir dağılımına sahip olanlardan daha kötü sağlık durumlarına sahip olabilirler. Dolayısıyla gelir yetersizliğinden dolayı oluşan yoksulluk, bireylerin yaşam süresini ve kalitesini olumsuz etkilemektedir. Bu nedenden dolayı bu zorluklarla yüzyüze kalan bireyler daha fazla hastalanmakta ve ortalamaya göre daha erken yaşta ölmektedir (61,
62). Adil gelir dağılımının olduğu topluluklarda sosyal uyum seviyesinin yüksek olduğu ve sosyal uyumun düştüğü anlarda ise sağlık risklerinin yükseldiği görülmektedir (60).

Eğitim bireylerin sosyoekonomik seviyelerini belirleyebildiği gibi eğitim sayesi sayesinde yükselen bilinçlilik düzeyi sağlık hizmetlerini kullanma durumunu da etkileyebilmektedir (63). Bireylerin eğitim düzeyi yükseldikçe gelir seviyelerinde, çalışma koşullarında ve nitelikli işlerde istihdam edilme olanakları artacağından dolayı yüksek standartı iyi yaşam koşullarında hayatlarını sürdürme olanakları artacak olmasından dolayı eğitimin ile sağlık arasında ilişkinin olduğu kabul edilmektedir (64). Eğitim düzeyi ile birçok hastalığın ortaya çıkması arasında doğrudan ilişki olduğunu gösteren çeşitli çalışmalar mevcuttur. Örneğin öğrenim düzeyi azaldıkça hipertansiyon görülme sıklı̆ı artmakta (65), gebelik sürecinde ve çocukların gerekli aşıları yaptırmasında annenin eğitim düzeyinin anlamlı bir fark yarattığını ortaya çıkmaktadır (66). Bebek ölüm hızının eğitim seviyesinin daha düşük olduğu yerlerde daha yüksek olduğu da yapılan araştırmalar ile saptanmıştır. Gelir kriterinde olduğu gibi bireylerin statüsünü belirleyen en önemli etkenlerden biri de eğitimdir. Eğitimin asıl amacı bilgi ve becerilerin bireyler tarafından kazanılmasını sağlamak ve böylece insanların eğitim seviyesi arttıkça mevcut sorunlar ile daha kolay baş etmelerini sağlamaktadır.

Sağlık ve çevre ilişkisinde yaşamış olduğumuz çevrenin getirdiği çeşitli risklerin; insanları doğrudan veya dolaylı olarak ekosistemleri etkileyerek sağlığı etki ettiği kanıtlamışıı. Endüstriyel tarımın yoğunlaşması, sanayileşme ve artan enerji kullanımı çevre sağlığı sorunlarının en şiddetli itici güçleridir (55). DSÖ raporlarına göre hava, su ve toprak kirliliği, çeşitli kimyasallara temas etme, iklim değişikliği ve ultraviyole radyasyon gibi risk faktörleri, çok sayıda hastalık ve sakatlığa neden olmaktadır (67).

Yazar Katkı Beyanı

Makalenin planlanması, verilerin elde edilmesi, istatistiksel analizlerin yapılması, yorumlanması, makalenin yazılması, son gözden geçirme: Fırat Kara, Makalenin dizaynı, istatistiksel analizlerin yorumlanması, makalenin yazılması: İlkay Öztürk.

\section{Çıkar Çatışması}

Yazarların çıkar çatışması durumu yoktur.

Finansal Destek

Yapılan araştırma konusu ile ilgili herhangi bir kurumdan finansal kaynak alınmamıştır.

\section{Etik Kurul Onayı}

İnsan örneği ve deneysel çalışma içermediğinden etik kurulu oluru gerekmemiştir. 
Hakemlik Süreci

Kör hakemlik süreci sonrası yayınlanmaya uygun bulunmuş ve kabul edilmiştir.

\section{KAYNAKLAR}

1. Keehley P, Macbridge SA. Can benchmarking for best practices work for government? Quality Progress 1997;30(3):75.

2. Seymen $\mathrm{OA}$, Bolat $\mathrm{T}$. Örgütsel öğrenme ve kıyaslama (Benchmarking) tekniğinin bir örgütsel öğrenme aracı olarak kullanılması. 1. baskı. Bursa: Ezgi Kitabevi, 2002;1-100.

3. Sargutan AE. Sağlık sektörü ve sağlık sistemlerinin yapısı. Hacettepe Sağlık İdaresi Dergisi 2005;8(3):400-428.

4. Çelebi KA, Cura S. Etkinlik göstergeleri açısından sağlık sistemleri: Karşılaştırmalı bir analiz. Maliye Dergisi 2013;164:47-67.

5. Kırılmaz H, Amarat M, Ünal Ö. Türkiye ve Amerika Birleşik Devletleri sağlık sistemlerinin karşılaştırmalı analizi. Strategic Public Management Journal 2017;3(6):78-104.

6. Camillo CA. Comparative healthcare systems. In Global Encyclopedia of Public Administration, Public Policy, and Governance 2017.

7. Terris M. Commentaries the three world systems of medical care: Trends and prospects. American Public Health Association 1978;68(11):1125-1131.

8. Field MG, Mark G. Success and crisis in national health systems: A comparative approach. Routledge Kegan \& Paul, 1989.

9. Elling RH. Theory and method for the cross-national study of health systems. International Journal of Health Services 1994;24(2):285-309.

10. Kılıç B, Aksakoğlu G. Sağlık sistemlerinin sınıflandırıımasına İlişkin Kuramsal Yaklaşımlar. Toplum ve Hekim 1994;9(6465):4-13.

11. Roemer MI. National health systems of the world volume I: The countries, New York. Oxford University Press, 1991.

12. Özmen Z. Avrupa'da sosyal güvenlik sisteminin finansmanı: Farklı refah devletleri üzerine bir inceleme. Sosyal Bilimler Enstitüsü Dergisi 2017;7(2):600-620.

13. World Health Organization (WHO): The world health report 2008 - primary health care (Now More Than Ever). In WHO. [İnternet yayını]. 2008 [Atıf 01.12.2019]. Erişim:https://www. who.int/whr/2008/en/

14. Kringos DS, Boerma WGW, Hutchinson A, Saltman RD, Saltman RB. Building primary care in a changing Europe. [İnternet yayını]. 2015 [Atıf 01.12.2019] Erişim: http:// www.euro.who.int/_data/assets/pdf_file/0018/271170/ BuildingPrimaryCareChangingEurope.pdf

15. TBMM. Türkiye Cumhuriyeti Anayasası, Pub. L. No. 2709, 1, 2017.

16. T.C. İçişleri Bakanlığı. e-içişLERi PROJESi. [ỉnternet yayını]. 2018. [Atıf: 10.12.2019] Erişim: https://www.e-icisleri.gov.tr/ Anasayfa/MulkildariBolumleri.aspx

17. Türkiye İstatistik Kurumu. Adrese Dayalı Nüfus Kayıt Sistemi Sonuçları, 2017. [İnternet yayını]. 2018a. [Atıf: 10.12.2019] Erişim:http://www.tuik.gov.tr/PreHaberBultenleri.do?id=27587
18. TUiK Nüfus projeksiyonları http://www.tuik.gov.tr/ PreHaberBultenleri.do?id=30567

19. TUiKK Gelir ve Yaşam Koşulları http://www.tuik.gov.tr/ PreHaberBultenleri.do?id=33821

20. Türkiye İstatistik Kurumu. Nüfus Projeksiyonları, 2018-2080. [internet yayını]. 2018c. [Atıf: 10.12.2019] Erişim:http://www. tuik.gov.tr/PreHaberBultenleri.do?id=30567

21. Türkiye İstatistik Kurumu. (2018d). Yıllık Gayrisafi Yurt İçi Hasıla, 2017. [internet yayını]. 2018d. [Atıf: 10.12.2019] Erişim: http://www.tuik.gov.tr/PreHaberBultenleri.do?id=27844

22. Resmî Gazete Sayı: 28261 İlköğretim ve Eğitim Kanunu İle Bazı Kanunlarda Değişiklik Yapılmasına Dair Kanun, Kanun No. 6287 Kabul Tarihi: 30/3/2012

23. OECD. Education at a Glance 2020: OECD Indicators. [İnternet yayını]. 2018. [Atıf: 19.09.2020] Erişim:https://doi. org/10.1787/69096873-en

24. Akdur R. Cumhuriyet'ten günümüze Türkiye'de sağlık politikaları. Rona Z. Bilanço, 1998;10-12. [İnternet yayını]. [Atıf: 10.04.2019] Erişim: http://www.recepakdur.com/upload/ CUMHURIYETTEN_GÜNÜMÜZE_TÜRKIYE.pdf

25. Özkaya H. Cumhuriyet döneminde bulaşıcı hastalıklarla mücadele. Türk Aile Hekimliği Dergisi 2016;20(2):77-84.

26. T.C. Sağlık Bakanlığı, Türkiye Sağlıkta Dönüşüm Programı Ilerleme Raporu. [Internet yayını]. 2008. [Atıf: 10.05.2019] Erişim: https://sbu.saglik.gov.tr/Ekutuphane/kitaplar/ turkiyeSDP.pdf

27. TBMM. 1961 Anayasası, Pub. L. No. 10816, 1,1961a.

28. TBMM. Sağlık hizmetlerinin sosyalleştirilmesi hakkında kanun, Pub. L. No. 224, 1, 1961b.

29. Cansever İH. Devlet anlayışları ekseninde sağlık politikalarının değişimi ve analizi: Türkiye incelemesi. Süleyman Demirel Üniversitesi Sosyal Bilimler Enstitüsü Dergisi 2018;(2):105120.

30. Elbek O, AdaşBE. Sağlıkta dönüşüm: Eleştirel bir değerlendirme. Türkiye Psikiyatri Derneği Bülteni 2009;12(1):33-44.

31. Kasapoğlu A. Türkiye'de sağlık hizmetlerinin dönüşümü. Journal of Sociological Research 2016;19(2):131-174.

32. OECD, Dünya Bankası. OECD Sağlık Sistemi İncelemeleri Türkiye. [İnternet yayını]. 2009. [Atıf: 21.05.2020] Erişim: www. sourceoecd.org/socialissues/9789264051089.

33. Yenimahalleli YG. Türkiye'de 1980 sonrası sağlık politikalarında gözlenen neoliberal dönüşüm ve sonuçları üzerine değerlendirmeler. Mülkiye Dergisi. 2008;XXXII(260):157-192.

34. T.C. Cumhurbaşkanlığı. Cumhurbaşkanlığı teşkilatı hakkında cumhurbaşkanlığı kararnamesi, Pub. L. No. 30474, 1, 2018.

35. T.C. Sağlık Bakanlığı. Toplum sağlığı merkezi ve bağı birimler yönetmeliği, Pub. L. No. 29258, 1, 2015.

36. OECD, European observatory on health systems and policies. State of health in the EU Spain country health profile 2017. [Internet yayını]. 2017. [Atıf: 09.12.2019] Erişim: https://doi. org/10.1787/888933593836

37. Bernal E, Sandra D, Juan GA, Fernando O, Sánchez Martínez I, Ramón J, ve ark. Spain Health system review. In: Health systems in Transition (Vol. 20). [İnternet yayını]. 2018. [Atıf: 02.02.2020] Erişim: www.healthobservatory.eu

38. Ministerio de Sanidad, Consumo y Bienestar Social - Portal Estadístico del SNS - Sanidad en datos. (n.d.). [İnternet yayını]. 2019. [Atıf: 05.07.2019] Erişim: https://www.mscbs.gob.es/ estadEstudios/sanidadDatos/home.htm 
39. INEbase/ Demografía y población. (n.d.). Fenómenosdemográficos. [İnternet yayını]. 2019. [Atıf: 05.07.2019] Erişim: https://www.ine.es/dyngs/INEbase/es/ categoria.htm?c=Estadistica_P\&cid=1254735573002

40. OECD Economic surveys Spain. [İnternet yayını]. 2017. [Atıf: 05.05.2019] Erişim: https://doi.org/10.1787/888933458795

41. Sargutan AE. Sağlık sektörü ve sağlık sistemlerinin yapısı. Hacettepe Sağlık İdaresi Dergisi 2005;8(3):400-428.

42. Gasparini L, Tornarolli L. A review of the OECD income distribution database. The Journal of Economic Inequality 2015;13(4):579-602.

43. OECD Income distribution data rewiew- Spain. [İnternet yayını]. 2012. [Atıf: 05.07.2019] Erişim: www.oecd.org/social/ inequality.htm

44. Instituto Nacional de Estadistica. Productos y Servicios / Publicaciones / Productos y Servicios / Publicaciones / Publicaciones de descargagratuita. [Internet yayını]. 2018. [Atıf: 05.06.2019] Erişim: https://www.ine.es/ss/Satellite?L=es_-ES \&C=INESeccion_C\&cid $=1259925953043 \& p=1254735110672$ \&pagename=ProductosYServicios\%2FPYSLayout\&param1=P YSDetalle\&param3=1259924822888

45. García-Santesmases P, Monteagudo JL. Final report on the KISA and innovation health care study in Spain personal care services for the elderly and chronic patients using information and communication technologies. [internet yayını]. 2004. [Atıf: 13.04.2019] Erişim: http://www.isciii.es/publico/

46. 2018 Global Reference List of 100 Core Health Indicators (plus health-related SDGs). Geneva: World Health Organization; 2018. Licence: CC BY-NC-SA 3.0 IGO

47. OECD stats. [İnternet yayını]. 2019. [Atıf: 03.07.2019] Erişim: https://stats.oecd.org/Index.aspx?DataSetCode=SHA\& $\mathrm{ga}=2.205218518 .710736184 .1546017739$. 1683871365.1545324550\#;

48. Indicadores Clave Sistema Nacional de Salud [internet yayını]. 2019. [Atıf: 02.08.2019] Erişim: https://www.mscbs.gob.es/ estadEstudios/sanidadDatos/home.htm.

49. World health statistics 2020: Monitoring health for the SDGs, sustainable development goals. Geneva: World Health Organization; 2020. Licence: CC BY-NC-SA 3.0 IGO.

50. WHO. Europen health report; Building primary care in a changing Europe No:38 Spain Health Systems in Transition 2018;20.

51. Mirowsky J, Ross C. Education, personal control, lifestyle and health - A human capital hypothesis. Research on Aging 1998;20(4):415-449.

52. Nesanır N, Düzkalır H, Göktolga G, Ekin F, Ersin C, Eser E. Manisa ilinde bir sağlık ocağı bölgesinde sağlıkta eşitsizlikler Sürekli Tıp Eğitimi Dergisi 2005;14(10):221-228.
53. Belek í. Algılanan sağlıkta sınıfsal ve sosyoekonomik eşitsizlikler: Antalya'da bir alan çalışması. Toplum ve Hekim 1998;13(4):292-299.

54. Ergin I, Hassoy H. Bebek ölümlülüğünde eşitsizlikler: Dünya ve Türkiye'deki duruma dair bir değerlendirme. İzmir Dr. Behçet Uz Çocuk Hastalıkları Dergisi 2011;1(3):98-104.

55. Kyriaki R, Phoebe K. Environmental effects on public health: An economic perspective. International Journal Environ Research Public Health 2009;6(8):2160-2178.

56. Whitehead M, Dahlgren $\mathrm{G}$. What can be done about inequalities in health? Lancet 1991;338:1059-1063.

57. TC Resmî Gazete Tarihi: 25.01.2013 Resmî Gazete Sayısı: 28539.

58. TC Sağlık Bakanlığı, Türkiye Kalp Ve Damar Hastalıkları Önleme Ve Kontrol Programı Eylem Planı (2015-2020), ISBN:978-975-590-553-2 TC Sağlık Bakanlığı Yayın No: 988 Ankara, 2015.

59. WHO. Socıal Determınants Of Health The Solid Facts. World Health Organization Second Edition. Ed. Winkinson R, Marmot M., Danimarka, 2003.

60. Marmot M. Social determinants of health inequalities. Lancet 2005;365:1099-104.

61. Şantaş F. Yoksulluğun sağlık statüsü ve sağlık hizmetleri kullanımı ile ilişkisi. Iğd Üniv Sos Bil Der 2017;13:545-591.

62. Polat G, İçağasıoğlu Çoban A. 21. yy'da sağlıkta eşitsizlikler ve eşitsizliğin aşılmasında sosyal hizmetin rolü. Toplum ve Sosyal Hizmet 2015;26(1):177-189.

63. Tekingündüz $S$, Kurtuldu $A$, Işık Erer $T$. Sağlık hizmetlerinde eşitsizlik ve etik. Aksaray Üniversitesi IïBF Dergisi 2016;8(4):3243.

64. Mirowsky J, Ross C. Education, personal control, lifestyle and health - A human capital hypothesis. Research on Aging 1998;20(4):415-449.

65. Hacıalioğlu N, Güraksın A, İnandı T. Gümüşhane ili Torul Merkez Sağlık Ocağı Bölgesi 30 yaş ve üzeri nüfusta hipertansiyon prevalansı ve ilgili etmenler. Türkiye Klinikleri Tıp Bilimleri Dergisi 1999;19(4):200-208.

66. Ergin I, Hassoy H. Bebek Ölümlülüğünde eşitsizlikler: Dünya ve Türkiye'deki duruma dair bir değerlendirme. İzmir Dr. Behçet Uz Çocuk Hastalıkları Dergisi 2011;1(3):98-104.

67. Prüss-Ustün A, Wolf $\mathrm{J}$, Corvalán $\mathrm{Ci}$, Bos $\mathrm{R}$, Nei M. Preventing disease through healthy environments a global assessment of the burden of disease from environmental risks. World Health Organization, 2016. 